\title{
Quantifying the annual fish harvest from South Africa's largest freshwater reservoir
}

\author{
BR Ellender ${ }^{1}$, OLF Weyl ${ }^{2,1 *}$, H Winker ${ }^{1}$ and AJ Booth ${ }^{1}$ \\ ${ }^{1}$ Department of Ichthyology and Fisheries Science, Rhodes University, Grahamstown 6140, South Africa \\ ${ }^{2}$ South African Institute for Aquatic Biodiversity, Private Bag 1015, Grahamstown 6140, South Africa
}

\begin{abstract}
South African inland fisheries are poorly developed and their contribution to near-shore communities is poorly understood. This study is the first comprehensive assessment of recreational and subsistence angling undertaken in an inland fishery in South Africa. The study was conducted on the $360 \mathrm{~km}^{2}$ Lake Gariep, South Africa's largest freshwater reservoir. A total of 508 anglers were interviewed between February 2007 and January 2008. Of those interviewed, 67\% were subsistence anglers and 33\% recreational anglers. Catch per unit effort (CPUE) did not differ significantly between sectors. CPUE fluctuated seasonally, ranging between $0.37(95 \% \mathrm{CI}=0.26$ to 0.51$) \mathrm{kg}$.angler ${ }^{-1} \cdot \mathrm{h}^{-1}$ in winter and $0.88(0.67$ to 1.17$) \mathrm{kg}$.angler ${ }^{1} \cdot \mathrm{h}^{-1}$ in summer. The duration of a fishing day ranged from $5.99(5.24$ to 6.74$) \mathrm{h}$ in mid-winter to 7.26 (6.88 to 7.63$) \mathrm{h}$ in early summer. Expected end-of-day catch (CPUE $\times$ fishing-trip duration) ranged from 2.2 to $6.4 \mathrm{~kg} \cdot$ angler ${ }^{-1} \cdot \mathrm{d}^{-1}$ depending on the season. The number of anglers ranged from 22 ( 8 to 53 ) anglers $\cdot \mathrm{d}^{-1}$ in June/July to 74 (25 to 176$)$ anglers $\cdot \mathrm{d}^{-1}$ in April. Total annual catch from the roving creel survey was estimated at 71.4 (57.4 to 91.4) $\mathrm{t}^{\cdot} \mathrm{yr}^{-1}$. Another $7.5 \mathrm{t} \cdot \mathrm{yr}^{-1}$ were landed during recreational angling competitions. The resultant total catch divided by the lakeshore population equated to a per capita fish supply of $11.1 \mathrm{~kg} \cdot \mathrm{yr}^{-1}$. More than $70 \%$ of the catch was the alien invasive carp Cyprinus carpio and there was no evidence of overfishing. The fish resource of Lake Gariep is of significant recreational and subsistence value. As a result of the low fish price (ZAR5.72 $\pm 2.60 \cdot \mathrm{kg}^{-1}$ ) subsistence fishing was considered a low-revenue activity that mainly augmented food security in lakeshore communities. The relatively high CPUE indicated that the fishery may be an important safety-net during periods when alternate sources of livelihoods are limited. Consequently, we recommend that the importance of angling to local communities needs to be taken into account when planning fisheries development and developing an inland fisheries policy.
\end{abstract}

Keywords: CPUE, annual yield, livelihoods, hurdle model, roving creel survey, Gariep Dam, angling

\section{Introduction}

African inland fisheries are generally important contributors to the livelihoods and food security of populations living within their vicinity. The South African situation differs from this in that formal inland fisheries are poorly developed and despite the existence of $3000 \mathrm{~km}^{2}$ of inland reservoirs national inland fisheries' yields are not formally assessed (Weyl et al., 2007). Fish from these reservoirs are utilised primarily by subsistence and recreational anglers (Ellender, 2009; Weyl et al., 2007). Despite provincial licensing requirements for these sectors, participation is limited and most of these fisheries are de facto open-access resources (Weyl et al., 2007). This can result in high effort and unsustainable harvest rates which could lead to overfishing. Such effects have led to the increasing global recognition that the impact of recreational angling (fishing with a rod, line and hook) on fish stocks is as significant as that of many commercial fisheries (Arlinghaus et al., 2005; Cooke et al., 2006). South Africa is no exception: In Hartbeespoort Dam, Cochrane (1987) estimated that recreational anglers harvested $695 \mathrm{t} \cdot \mathrm{yr}^{-1}$ (348 $\left.\mathrm{kg} \cdot \mathrm{ha}^{-1} \cdot \mathrm{yr}^{-1}\right)$ between 1982 and 1984.

\footnotetext{
* To whom all correspondence should be addressed.

표 +2746 6035834; fax: +27466222403 ;

e-mail: o.weyl@saiab.ac.za

Received 19 August 2009; accepted in revised form 30 November 2009.
}

In South Africa inland fisheries are utilised almost exclusively by anglers (persons that attempt to catch fish with a hook attached to a line) that fish on either a subsistence or recreational basis (Ellender et al. 2009). While recreational angling remains a major contributor to fish harvests, increased utilisation of fish resources by the shore-based subsistence anglers is becoming more common (Ellender et al., 2010). As a result, subsistence angling is likely to contribute to the livelihoods in communities living adjacent to such resources.

In South Africa, this is particularly relevant because of the potential of inland fisheries in achieving major national policy objectives such as food security, economic empowerment, tourism development, optimal economic benefit from water, and poverty alleviation (Weyl et al., 2007). With the recent mandate of the Department of Agriculture being extended to include fisheries, it is likely that there will be an increased interest in fisheries development. It is important that such development is based not only on information on the resource itself but also on the utilisation patterns of existent resource users.

This study presents the first comprehensive assessment of angling catch and effort, based on roving creel surveys (RCS), in any inland fishery in South Africa. The objective of this assessment was to determine individual catch per unit effort (CPUE) to quantify individual shore angler harvest and to assess the importance of angling to household fish supply, to determine annual angling catch and assess the likelihood of overfishing. 


\section{Methods}

\section{Study site}

Lake Gariep (30 $\left.38.703^{\prime} \mathrm{S}, 25^{\circ} 46.998^{\prime} \mathrm{E}\right)$ is situated on the Orange River system in central South Africa. This hydroelectric and water supply reservoir was completed in September 1970. At maximum capacity it has a surface area of $360 \mathrm{~km}^{2}$, a $400 \mathrm{~km}$ shoreline and an average depth of $16.3 \mathrm{~m}$ (Hamman, 1981). The lakeshore is characterised by gradually sloping muddy shores $(90 \%)$ and steep rocky areas $(10 \%)$ (Cambray et al., 1978). The shoreline is largely devoid of vegetation due to both wind action and frequent, rapid fluctuations in water level (Hamman, 1981). The inflowing upper Orange River has relatively low concentrations of dissolved chemicals (electrical conductivity $70 \mu \mathrm{s}^{\cdot} \mathrm{cm}^{-1}$ to $100 \mu \mathrm{s}^{\cdot} \mathrm{cm}^{-1}$ ), but high levels of suspended sediments (mean Secchi depth $=$ $15 \mathrm{~cm}$ ) (Ellender, 2009) and the lake has been characterised as a turbid oligo-mesotrophic impoundment (Keulder, 1979).

The fish community is dominated by large cyprinids particularly the South African endemic Orange River mudfish Labeo capensis (A. Smith, 1841), moggel Labeo umbratus (A. Smith, 1841), smallmouth yellowfish Labeobarbus aeneus (Burchell, 1822), largemouth yellowfish Labeobarbus kimberleyensis (Gilchrist and Thompson, 1913) and the alien invasive common carp Cyprinus carpio (Linnaeus, 1754). Other species include the African catfish Clarias gariepinus (Burchell, 1822), the small chubbyhead barb Barbus anoplus (Weber, 1897) and alien salmonids and centrarchids.

The fishing areas and angler user groups, their demographics and access to the fishery have been described in detail by Ellender et al. (2009; 2010). The impoundment is situated between the Northern Cape, Eastern Cape and Free State Provinces in central South Africa, and its entire 400 $\mathrm{km}$ shoreline falls under the jurisdiction of 2 local nature conservation authorities (Eastern Cape Parks and Free State Nature Conservation). Most of the shoreline is closed to angling but open-access fishing regions have been allocated near 3 residential areas situated on the shoreline: Gariep Dam (S30 36.721, E25 29.663), Venterstad (S30 46.531, E25 47.901) and Bethulie (S30 30.081, E25 58.554). Bethulie, in the Free State Province, was excluded from this assessment because preliminary surveys showed that residents only fished in a shallow pan that was not connected to the lake except at very high lake levels. In the main lake, 2 x $35 \mathrm{~km}$ fishing areas have been designated for anglers from the residential areas of Gariep Dam (population 1 018) and Venterstad (population 4 846) (Statistics South Africa, 2003), which are referred to as Gariep Dam fishing area (GDFA) and Venterstad fishing area (VSFA), respectively (Fig. 1). Access to these areas is controlled by the nature conservation authorities and allowed only between 06:00 and18:00. Night fishing is not permitted and there is no other access to the lakeshore. Angling is undertaken with either hand-lines or spinning reels attached to fibreglass or graphite fishing rods. Hooks are generally small (Size 8 to 2) and are baited with flour dough, maize, worms, berries or commercially available baits.

\section{Creel surveys}

To estimate seasonal catch rates, randomly stratified roving creel surveys (RCS) were conducted on a bi-monthly basis in the 2 fishing regions (GDFA and VSFA, Fig. 1.) from February 2007 to January 2008. Each survey comprised a

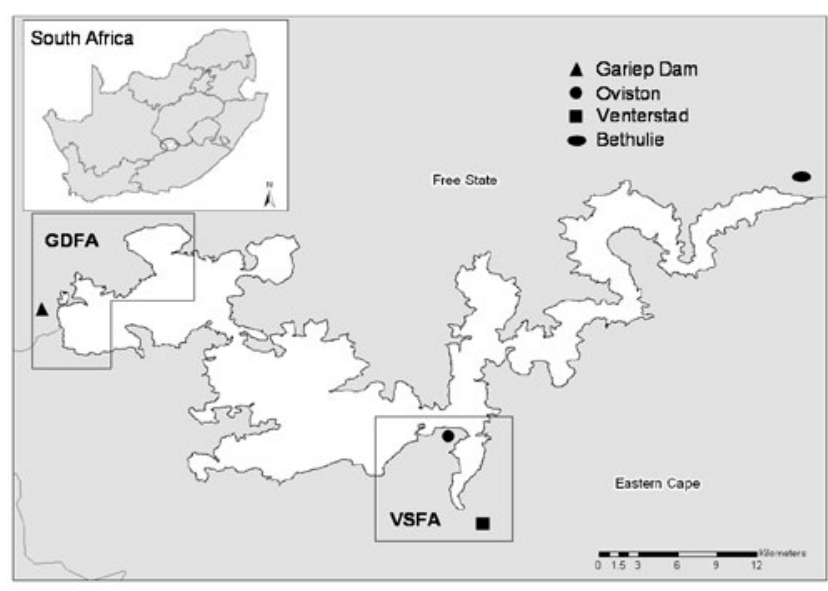

Figure 1

Location of the Gariep Dam in South Africa (insert) and enlarged map of Lake Gariep, showing the location of the Gariep Dam fishing area (GDFA) Venterstad fishing area (VSFA) and nearby towns.

2-week sampling event, with a $7 \mathrm{~d}$ assessment period in each of the sampling regions. The sequence of regions sampled was randomised and for sampling purposes, each region was divided into a number of strata. RCSs were conducted on three randomly selected week days and on both weekend days in each region. On any sampling day, the surveyor moved unidirectionally through the stratum stopping only for angler interviews. The daily survey was terminated when all anglers were interviewed within that particular stratum or the fishing area closed at 18:00. During the interview, the time that fishing was initiated, the expected end time of the fishing day and the gear used were recorded. All captured fish were identified, weighed collectively by species, and then measured individually (nearest $\mathrm{mm}$ fork length FL). Fishing effort was estimated using an angler count from a fixed position vantage point in the morning and afternoon of each sampling day.

\section{Catch per unit effort}

Individual CPUE for each interviewed angler was expressed as:

$$
\text { CPUE }\left(\mathrm{kg} \cdot \text { angler }^{-1} \cdot \mathrm{h}^{-1}\right)=\frac{\operatorname{catch}(\mathrm{kg})}{\text { time fished }(h)}
$$

As is often the case, the CPUE data were right-skewed and contained a high proportion of zero observations (Fig. 2A). This is a common problem with CPUE data and in such cases the use of a zero-altered model based on a delta-X distribution has become the standard analysis to derive more realistic estimates of confidence around the estimate for CPUE (Lo, 1992; Steffanson et al., 1996; Punt, 2000; Maunder and Punt 2004; Fletcher, 2005). In this approach, delta is the probability of a non-zero observation occurring and $\mathrm{X}$ refers to the distribution of these non-zero observations. The application of this approach to our data is summarised in Fig. 2. The non-zero CPUE observations $\left(C P U E_{\text {pos }}\right)$ were log-normally distributed (Fig. 2B) and the expected $C P U E$ was calculated by scaling $C P U E_{p o s}$ by the probability of an interviewed angler in the sample having caught a fish (PC) (Fig. 2C). CPUE for any sampling period $i, C P U E_{i}$, was therefore expressed in the form of a deltalognormal model:

$$
C P U E_{i}=P C_{i} \times \exp \left(\log C P U E_{p o s, i}+\frac{\sigma^{2}}{2}\right)
$$


where:

$P C_{i}$ is the probability of the interviewed angler having captured a fish during period $i, \log C P U E_{p o s, i}$ are the $\log$ transformed $C P U E_{\text {pos }}$ observations during period $i$ $\sigma^{2}$ is the variance of $\log C P U E_{p o s, i}$ (Fig. 2C)

\section{Total catch}

Total catch $\left(T C_{d a y, i}\right)$ for any day during sampling period was estimated in $\mathrm{kg} \cdot \mathrm{d}^{-1}$ as:

$$
T C_{d a y, i}\left(k g \cdot d^{-1}\right)=\overline{C P U E_{i}} \times \overline{E_{i}}
$$

where:

$\bar{E}_{i}$ is the mean effort on any day during sampling period $i$ and is calculated as:

$$
\bar{E}_{i}=D L_{i} \times \bar{A}_{i}
$$

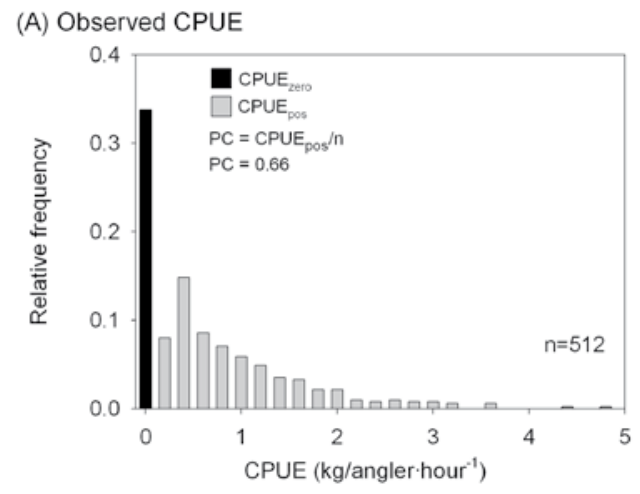

(B) Natural logarithm transformed CPUE

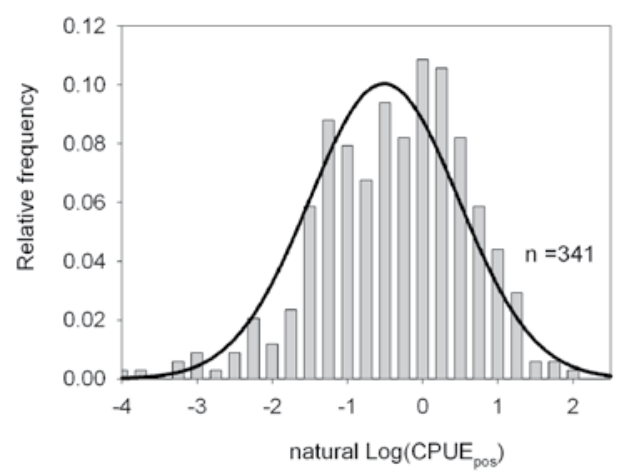

(C) Delta-X transformation of CPUE

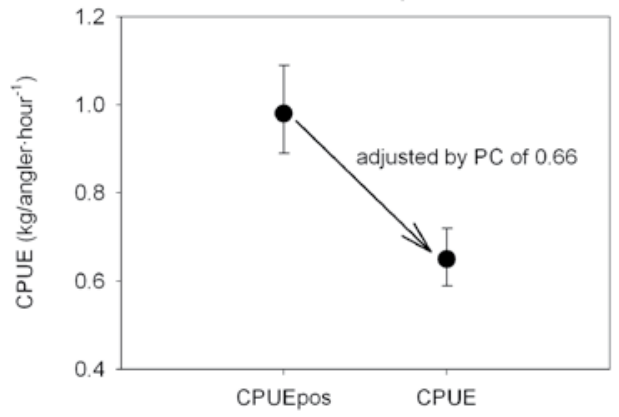

Figure 2

Frequency distribution of CPUE (A), log-normal distribution of CPUE (CPUE excluding zero catches) $(B)$ and the CPUE scaling (C) for angler catches in Lake Gariep between February 2007 and January 2009. Error bars denote 95\% confidence intervals. where:

$D L_{i}$ is the mean duration of the angling trip (estimated by subtracting the angling start-time from the predicted end-time)

$\bar{A}_{i}$ is the expected mean number of anglers on the lakeshore on any day during sampling period $i$.

This was calculated as:

$$
\bar{A}_{i}=\sum_{h}^{n} \frac{\sum A_{h, i}}{m_{h, i}} / n_{i}
$$

where:

$A_{h, i}$ is the number of anglers on the $h^{\text {th }}$ day, observed during instantaneous fixed position effort counts $m_{h, i}$ is the number of instantaneous fixed position counts on the $h^{\text {th }}$ day

$n_{i}$ is the number of sampling days during sampling period $i$

Total annual catch $T C_{y r}$ was then calculated as:

where:

$$
T C_{y r}\left(t \cdot y r^{-1}\right)=\sum_{i=1}^{6} T C_{i}\left(k g \cdot d^{-1}\right) \times 60 d / 1000
$$

$T C_{i}$ was converted to tons with a $60 \mathrm{~d}$ bi-monthly period

\section{Confidence intervals}

The analytical derivations of confidence intervals around estimates of PC, CPUE and effort are complicated by the nature of the data. PC data are binomial, CPUE ${ }_{p o s}$ data are log-normally distributed and angler counts are based on a temporally and spatially stratified sampling regime. In such cases bootstrapping is considered the most appropriate method for deriving confidence intervals (Maunder and Punt, 2004). Confidence intervals for $C P U E_{p o s}, P C$, effort and total catches were estimated using a nonparametric bootstrapping procedure (Efron and Tibshirani 1996). For this purpose, data sets with observations for $P C_{i}, \log C P U E_{p o s, i}, D L_{i}$ and $\bar{A}_{i}$ were re-sampled randomly with replacement 1000 times for each sampling trip $i$ and Eqs. (2) to (6) were applied to each randomly generated data $\operatorname{set}\left(B_{u}: U=1,2, \ldots, 1000\right)$. The percentile method (Buckland, 1984) was used to estimate $95 \%$ confidence intervals from the resulting bootstrap vectors, where the $2.5 \%$ and $97.5 \%$ percentiles were chosen to obtain the lower and upper $95 \%$ confidence intervals, respectively.

\section{Competition angling catches}

Total catch data recorded during formal angling competitions were obtained from the event orgizisers which included the Eastern Cape Bank Anglers Association and the South African Police who have annual competitions on Lake Gariep. These competition catch statistics contained the weight of all fish caught by each competitor, so that the sum of individual catches corresponded to the absolute catch from competitions during the study period. To obtain an estimate of the total catch from Lake Gariep, the absolute catch from angling competitions was added to the estimates from the RCS.

\section{Potential for overfishing}

To assess for potential overfishing the mean length of all fish measured was calculated and compared with the length at maturity reported for these species in Lake Gariep by Hamman (1981). In addition, the total catch per hectare was estimated by 
dividing the TC by the total surface area of the lake at full supply level and comparing this to yields reported by Crul (1992) for 71 other African fisheries.

\section{Food security and economic value of the catch}

To obtain an estimate of the value of the catch, anglers were asked at the end of their fishing trip whether they were going to sell part of their catch, and the asking price for each individual fish. Fish that were to be sold were weighed to determine price per kilogram. To obtain an estimate of the total quantities of fish consumed or donated, released and sold for the assessment year was obtained by dividing total catch estimates from this paper by data (obtained from Ellender et al., 2009) on the proportion of respondents that primarily consumed (61.6\%), gave away $(4.1 \%)$, released $(8.7 \%)$ or sold $(25.6 \%)$ their catch. The total value of sold fish was then estimated as the product of quantity sold $\times$ fish price. Fish caught during angling competitions was considered released although a portion of this catch was, occasionally, donated for research or the local community. The per capita fish supply from the dam was then obtained by dividing the estimated quantity of fish consumed, donated and sold by the total population in settlements adjacent to the study area.

\section{Results}

Five hundred and eight creel survey interviews were conducted between February and December 2007. Of these, 67\% were with subsistence and $33 \%$ with recreational anglers.

\section{Species composition}

Five species were recorded in angler catches; carp (Cyprinus carpio), Orange River mudfish (Labeo capensis), smallmouth yellowfish (Labeobarbus aeneus), largemouth yellowfish (Labeobarbus kimberleyensis) and the African sharptooth catfish Clarias gariepinus (Table 1). Numerically and by weight, carp dominated the catch composition with none of the other species contributing more than $8 \%$ to the catch by weight.

\section{Catch and effort}

Sixty-six per cent of all anglers interviewed had caught at least a fish and $C P U E_{\text {pos }}$ did not differ significantly between sectors (Man-Whitney $U$ test, $\mathrm{p}>0.05$ ) but differed significantly between periods (Kruskall-Wallis by ranks, $\mathrm{df}=5, \mathrm{p}<0.05$ ). As a result, RCS data for recreational and subsistence anglers were combined for analysis but all analyses were disaggregated by period. The mean annual CPUE was calculated as $0.65(95 \%$ $\mathrm{CI}=0.57$ to 0.74$) \mathrm{kg} \cdot$ angler $^{-1} \cdot \mathrm{h}^{-1}$ (Fig. $2 \mathrm{C}$ ).

The probability of an interviewed angler having caught a fish $(\mathrm{PC})$ was lowest in late winter $(\mathrm{Aug} / \mathrm{Sept} \mathrm{PC}=0.49)$ and highest in early summer (Oct/Nov $\mathrm{PC}=0.80)$ (Fig. 3A). CPUE fluctuated between $0.37(0.26$ to 0.51$) \mathrm{kg} \cdot$ angler $^{-1} \cdot \mathrm{h}^{-1}$ in winter (Jun/Jul) and 0.88 (0.67 to 1.17$) \mathrm{kg} \cdot$ angler $^{-1} \cdot \mathrm{h}^{-1}$ in early summer (Oct/Nov). The mean duration of a fishing day was shortest in winter (5.99 (5.24 to 6.74) h) (June/July) and longest (7.26 h (6.88 to 7.63$)$ ) in early summer (Oct/Nov) (Fig. 3C) The expected end-of-day catch (CPUE $\times$ fishing-trip duration) ranged between 2.2 and $6.4 \mathrm{~kg} \cdot$ angler $^{-1} \cdot \mathrm{d}^{-1}$ depending on the sampling period. The total number of anglers fishing ranged between 22 ( 8 to 53 ) anglers $\cdot \mathrm{d}^{-1}$ in winter (June/July) and 74 (25 to 176 ) anglers $\cdot \mathrm{d}^{-1}$ in autumn (April/May). Total daily catch $T C_{i}$
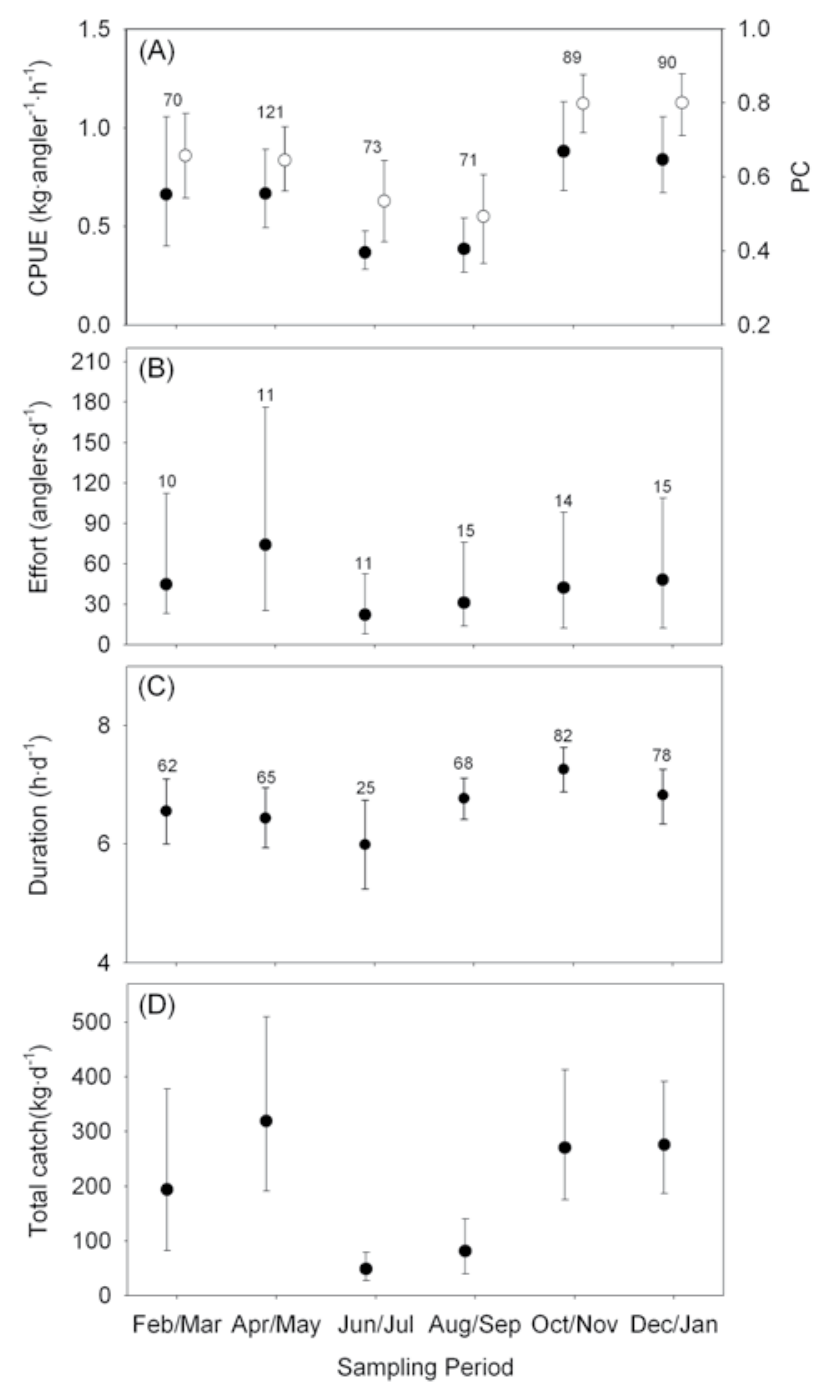

Figure 3

(A) Mean catch per unit effort CPUE (black circles, left axis) and the probability of an angler having caught a fish at the time of the interview PC (white circles, right axis); (B) mean number of anglers fishing; (C) duration of fishing day and (D) total catch per day from Lake Gariep, South Africa. Error bars denote 95\% confidence intervals; numbers above error bars denote number of observations.

during that period was lowest in winter at 49 (27 to 79$) \mathrm{kg} \cdot \mathrm{d}^{-1}$ and highest $\left(T C_{i}, 319\right.$ (191to 511) $\left.\mathrm{kg} \cdot \mathrm{d}^{-1}\right)$ during the autumn period (April/May) (Fig. 3D). Total annual catches from roving creel surveys and the recreational angling competitions were 71.4 (57.4 to 91.4) $\mathrm{t}^{\mathrm{y}} \mathrm{yr}^{-1}$ and $7.5 \mathrm{t} \cdot \mathrm{yr}^{-1}$ respectively. Total catch (TC) was estimated at $78.9 \mathrm{t} \cdot \mathrm{yr}^{-1}$.

\section{Potential for overfishing}

Mean length at capture was larger than size at maturity for all species except $C$. gariepinus and L. kimberleyensis (Table 1). Total catch per unit area was estimated at $2.17 \mathrm{~kg} \cdot \mathrm{ha}^{-1} \cdot \mathrm{yr}^{-1}$ at Lake Gariep's full supply level.

\section{Food security and economic value of the catch}

Only 17 anglers provided accurate estimates of their expected selling price for fishes in their catch. The mean fish price was 


\begin{tabular}{|c|c|c|c|c|c|}
\hline \multicolumn{6}{|c|}{$\begin{array}{l}\text { Table } 1 \\
\text { Species composition expressed as a per cent of total number }(\mathrm{n}=2340 \text { fish) and total weight }(\mathrm{n}=2139 \mathrm{~kg}) \\
\text { of fish caught by anglers interviewed on Lake Gariep between February } 2007 \text { and January } 2009 . \\
\text { Mean length of fish in the catch (Length) and length at maturity }\left(L_{50}\right) \text { are provided. } \mathrm{FL}=\text { fork length, } \\
T L=- \text { total length, } n=\text { sample size. }\end{array}$} \\
\hline \multirow[t]{2}{*}{ Common name } & \multirow[t]{2}{*}{ Species } & \multicolumn{2}{|c|}{ Catch composition } & \multirow{2}{*}{$\begin{array}{l}\text { Length } \\
\text { (cm) }\end{array}$} & \multirow{2}{*}{$\begin{array}{c}\mathrm{L}_{50} \\
(\mathrm{~cm})^{*}\end{array}$} \\
\hline & & No. (\%) & Mass (\%) & & \\
\hline Common carp & Cyprinus carpio & 72.1 & 78.5 & $36 \pm 6$ FL $(n=1567)$ & $30 \mathrm{FL}$ \\
\hline African sharptooth catfish & Clarias gariepinus & 7.7 & 6.8 & $44 \pm 14$ TL $(n=178)$ & $46 \mathrm{TL}$ \\
\hline Orange river mudfish & Labeo capensis & 11.5 & 7.0 & $32 \pm 3$ FL $(n=233)$ & $29 \mathrm{FL}$ \\
\hline Smallmouth yellowfish & Labeobarbus aeneus & 8.5 & 7.5 & $37 \pm 4$ FL $(n=180)$ & $31 \mathrm{FL}$ \\
\hline Largemouth yellowfish & Labeobarbus kimberleyensis & 0.3 & 0.3 & $39 \pm 3$ FL $(n=6)$ & $44 \mathrm{FL}$ \\
\hline
\end{tabular}

ZAR5.72 $\pm 2.60 \mathrm{~kg}^{-1}$. Excluding the fish caught during fishing competitions, it was estimated that $46.9 \mathrm{t}^{-} \mathrm{yr}^{-1}$ were consumed or donated, $18.3 \mathrm{t} \cdot \mathrm{yr}^{-1}$ were sold and $6.2 \mathrm{t} \cdot \mathrm{yr}^{-1}$ were released. The total monetary value of the fish sold was ZAR104 676 $\mathrm{yr}^{-1}$. On the assumption that the sold fish were consumed locally, the total per capita fish supply from the dam was $11.1 \mathrm{~kg} \cdot \mathrm{capita}^{-1} \cdot \mathrm{yr}^{-1}$.

\section{Discussion}

In Africa, inland fisheries are generally synonymous with commercial artisanal fisheries that utilise gear types such as gill nets, seine nets and long-lines as harvest methods (Weyl et al., 2004; Weyl, 2008). Such fisheries are recognised as important for food security, livelihoods and economic activities (Allison et al., 2001) and catches are monitored at formal landing sites using established methods (Darwall et al., 2002; Cowx et al., 2003). This is not the case in South Africa: Commercial inland fisheries are undeveloped as a result of a history of limited access to resources and low cultural involvement in fishing, in addition to a lack of an inland fisheries policy and unclear national fisheries management objectives. The results from the Lake Gariep survey, however, indicate that despite the lack of commercial fisheries development, harvests by subsistence and recreational anglers are considerable and require recognition if commercial fisheries are to be developed. This is particularly relevant because, globally, the impacts of recreational and subsistence fisheries are increasingly recognised as being as significant as the impacts from commercial fisheries (Allison and Ellis, 2001; Arlinghaus et al., 2005; Cooke and Cowx, 2006).

\section{Angler harvest}

The probability of an angler capturing a fish and CPUE were the lowest in the winter and the highest during the summer. A reduced probability of capture in winter has been ascribed to reduced metabolic rate and the consequent reduction in feeding of fish during cold-water periods (Cooke et al., 2003). Fishing effort followed similar trends with increased effort in the warmer months when the overall CPUE was high. Such trends are common in angler-based fisheries and were also reported for recreational anglers in Hartbeespoort Dam, South Africa (Cochrane, 1987) and for subsistence anglers in the Mutshindudi catchment in the Limpopo Province (Van der Waal, 2000).

The mean CPUE of $0.65 \mathrm{~kg} \cdot$ angler ${ }^{-1} \cdot \mathrm{h}^{-1}$ was much higher than that recorded for other Southern African subsistence anglers:

$<0.2 \mathrm{~kg} \cdot$ angler $^{-1} \cdot \mathrm{h}^{-1}$ in Lake Chicamba, Mozambique

(Weyl, 2008)
$<0.06 \mathrm{~kg} \cdot$ angler $^{-1} \cdot \mathrm{h}^{-1}$ for the Mutshindudi River, Limpopo Province in South Africa (Van der Waal, 2000)

$<0.09 \mathrm{~kg} \cdot$ angler $^{-1} \cdot \mathrm{h}^{-1}$ in the Great Fish River estuary, South Africa (Potts et al., 2004).

The daily catch of 2.2 to $6.4 \mathrm{~kg} \cdot$ angler $^{-1} \cdot \mathrm{d}^{-1}$ was similar to the 3 to $8 \mathrm{~kg} \cdot$ angler ${ }^{-1} \cdot \mathrm{d}^{-1}$ reported by Cochrane (1987) for recreational anglers in the eutrophic Hartbeespoort Dam but was much higher than the $0.162 \mathrm{~kg} \cdot$ angler-1 $\mathrm{d}^{-1}$ reported for anglers in the Mutshindudi catchment (Van der Waal, 2000).

High CPUE in Lake Gariep may be indicative of low utilisation levels. Current estimated yield equates to only $2.5 \mathrm{~kg} \cdot \mathrm{ha}^{-1} \cdot \mathrm{yr}^{-1}$, an estimate that is well below the reported yields (13 to $281 \mathrm{~kg} \cdot \mathrm{ha}^{-1} \cdot \mathrm{yr}^{-1}$ ) from 71 African fisheries (Crul, 1992). In addition, only $18 \%$ of Lake Gariep's shoreline is open to angling and thus utilisation levels must be considered low.

\section{Importance of the fishery to food security}

While the lake is of importance to recreational anglers as a source of leisure, angling is also an important subsistence activity, with $67 \%$ of all angler interviews being conducted with subsistence anglers. Since the average household size in the surrounding area approximates 5.5 people (Statistics South Africa, 2003), it is evident that a daily catch of between 2.2 and $6.4 \mathrm{~kg} \cdot$ angler $^{-1} \cdot \mathrm{d}^{-1}$ is more than sufficient to meet household requirements. This is supported by angler interview data which showed that $41 \%$ of subsistence anglers and $25.6 \%$ of all interviewed anglers sold some of their catch (Ellender et al., 2009). At an average fish price of ZAR5.72 $\mathrm{kg}^{-1}$, the sale of fish from angling is a low- revenue activity. This must, however, be seen in the context of the prevailing economic conditions. Given that most subsistence anglers are unemployed and that $52 \%$ of the economically active population in the area have an income of $<\mathrm{R} 400 \cdot$ month $^{-1}$ (Ellender et al., 2009), fish generates at least some income in an area where opportunity costs are low. Furthermore, when fish price is compared to the midyear price of fresh whole chicken (ZAR23.72 $\mathrm{kg}^{-1}$; National Agricultural Marketing Council, 2007, pg 34.) it is evident that fish provides a cheap source of protein not only for angling households but also for non-angling households that purchase the fish. With continuously rising food prices, the importance of fish to the lakeshore community will most likely increase. It must also be noted that because catch rates were relatively high (despite some seasonal fluctuations) it is likely that the fishery is not only an important contributor to the food security in the area but may also be an important safety-net for the rural poor in times when alternative livelihood sources are limited. 


\section{Harvest patterns and sustainability}

While the relatively low annual total catch suggests that the fishery is most likely underutilised from a yield perspective, it is important to assess the species and size composition of the catch to evaluate whether utilisation patterns tend towards potential overfishing. Catches were dominated $(>70 \%)$ by one of the top 8 alien invasive freshwater fishes, the common carp (Lowe, 2000), which was harvested at lengths larger than size at maturity. As has been reported for other South African impoundments (Cadieux, 1980; Cochrane, 1987), common carp were the main target species of anglers. Other species appeared to be an incidental by-catch and were either also harvested at lengths greater than maturity or comprised such a small portion of the catch that they are unlikely to be threatened by the current harvest regime. Therefore, at current harvest levels, the fishery is most likely sustainable.

\section{Conclusions}

Despite the lack of a commercial fishing sector on Lake Gariep, recreational and subsistence sectors harvested an estimated $79 \mathrm{t}^{-} \mathrm{yr}^{-1}$ over the survey period. While local fish price and total catch value were low, the contribution of recreational angling to employment in the associated industry and subsistence angling to food security should not be underestimated. Future fisheries development must take the current utilisation of the fishery by subsistence and recreational anglers into account. This is because fish is a finite resource and CPUE generally decreases as total catch and effort on a fish stock increase. A decrease in CPUE in the Lake Gariep fishery would undoubtedly impact the recreational and subsistence fishery. A second, but equally important consideration is that a commercial fishery selling fish directly to lakeshore communities would most likely compete for markets with subsistence anglers. Ellender et al. (2010) estimated that the subsistence sector comprised more than 450 regular anglers. It is likely that only a small portion of these subsistence users might be employed by a commercial fishery. As a result, a commercial fishery would create economic empowerment for few while potentially endangering the livelihood of many. A comprehensive study of the impact of any new fishery on the local economy and on food security should therefore be conducted prior to the development of any fisheries. Multi-sectoral resource use is not confined to this case study and has been reported for reservoirs in the North West Province of South Africa (Weyl et al., 2007). In such cases, decisions on resource allocation should be guided by National policy, although at present, the lack of an inland fisheries policy is a major stumbling block for sustainable inland fisheries development in South Africa.

\section{Acknowledgements}

This material is based upon work supported by the National Research Foundation (NRF) of South Africa (FA2005021600012). Any opinion, findings and conclusions or recommendations expressed in this material are those of the authors and therefore the NRF does not accept any liability in regard thereto. Many thanks to James and Helen Carey from the Oviston Nature Reserve for all their assistance and hospitality and making it a home away from home. Thanks to the Eastern Cape Parks Board and Free State Nature Conservation staff for all their assistance as well as the staff from the Gariep State Fish Hatchery. The authors would also like to thank the Free State Province Department of Tourism,
Environmental and Economic Affairs for issuing a permit (HK/ P1/07871/001) to conduct the research. The Joint Research Committee of Rhodes University, Grahamstown, provided funding to support the writing of this manuscript. Recreational and subsistence fishers are thanked for allowing us to interview them and the Northern Cape and Free State Police anglers, the Eastern Province Freshwater Bank Angling Federation and the participants of the SAPS Championships, and the Suid-Afrikaanse Varswateroewerhengelfederasie provided us with their catch data.

\section{References}

ALLISON EH and ELLIS F (2001) The livelihoods approach and management of small-scale fisheries. Mar. Policy 25 377-388.

ARLINGHAUS R, COOKE SJ, COLEMAN FC, FIGUEIRA WF, UELAND JS and CROWDER LB (2005) Global impact of recreational fisheries. Sci. 307 1561-1563.

BUCKLAND ST (1984) Monte-Carlo confidence intervals. Biometrics 40 811-817.

CADIEUX JJ (1980) Freshwater angling in the Transvaal: its environmental and economic impact. S. Afr. J. Sci. 76 492-493.

CAMBRAY JA, HANDIEK S and HANDIEK Q (1978) The juvenile fish population in the marginal areas of the Hendrik Verwoerd Dam. J. Limnol. Soc. South. Afr. 4 21-30.

COCHRANE KL (1987) The biomass and yield of the dominant fish species in Hartbeespoort Dam, South Africa. Hydrobiol. 146 89-96.

COOKE SJ and COWX IG (2006) Contrasting recreational and commercial fishing: Searching for common issues to promote unified conservation of fisheries resources and aquatic environments. Biol. Cons. 128 93-108.

COOKE SJ, OSTRAND KG, BUNT CM, SCHREER JF, WAHL DH and PHILIPP DP (2003) Cardiovascular responses of largemouth bass to exhaustive exercise and brief air exposure over a range of water temperatures. Trans. Am. Fish. Soc. 132 1154-1165.

COWX IG, VANDERKNAAP M, MUHOOZI LI and OTHINA A (2003) Improving fishery catch statistics for Lake Victoria. Aquat Ecosyst. Health Manage. 6 299-310.

CRUL RCM (1992) Models for estimating potential fish yields of African inland waters. CIFA Occasional Paper 16 1-22.

DARWALL WRT and ALLISON EH (2002). Monitoring, assessing, and managing fish stocks in Lake Malawi/Nyassa: current approaches and future possibilities Aquat. Ecosyst. Health Manage. 5 293-305.

EFRON B and TIBSHIRANI R (1986) Bootstrap methods for standard errors, confidence intervals, and other measures of statistical accuracy. Stat. Sci. 1 54-77.

ELLENDER BR, WEYL OLF and WINKER H (2009) Who uses the fishery resources in South Africa's largest impoundment? Characterising subsistence and recreational fishing sectors on Lake Gariep. Water SA 35 679-684.

ELLENDER BR, WEYL OLF, WINKER H, STELZHAMMER H and TRAAS GRL (2010) Estimating angling effort and participation in a multi-user, inland fishery in South Africa. Fisheries Management and Ecology 17 (1) 19-27. doi: 10.1111/j.1365-2400.2009.00708.x.

ELLENDER BR (2009) The Impact of Angling on Smallmouth and Largemouth Yellowfish, Labeobarbus aeneus and Labeobarbus kimberleyensis, in Lake Gariep, South Africa. M.Sc. Thesis, Rhodes University, Grahamstown, South Africa. 111 pp.

FAO (2004) Strategies/mechanisms for improved reporting on inland capture fisheries and inland aquaculture. Proc. $13^{\text {th }}$ Session of the Committee for Inland Fisheries of Africa. 27-30 October 2004, Entebbe, Uganda. CIFA/XIII/2004/4. 11 pp.

FLETCHER D, MACKENZIE D and VILLOUTAS E (2005) Modelling skewed data with many zeros: A simple approach combining ordinary and logistic regression. Environ. Ecol. Stat. 12 45-54.

HAMMAN KCD (1981) Aspekte van die Bevolkingsdinamika van die Hendrik Verwoerddam met Verwysing na die Ontwikkeling van ' $\mathrm{n}$ Visserybestuursplan. Ph.D. Thesis, Rand Afrikaans University, Johannesburg, South Africa. 
KEULDER PC (1979) Hydrochemistry of the upper Orange River catchment. J. Limnol. Soc. South. Afr. 5 39-46.

LO NC, JACOBSON LD and SQUIRE JL (1992) Indices of relative abundance for fish spotter data based on delta-lognormal models. Can. J. Fish. Aquat. Sci. 49 2515-2526.

MAUNDER MN and PUNT A (2004) Standardizing catch and effort: a review of recent approaches. Fish. Res. 70 171-195.

O'NEILL MF and FADDY MJ (2003) Use of binary and truncated binomial modelling in the analysis of recreational catch data. Fish. Res. 60 471-477.

POLLOCK KH, HOENIG JM, JONES CM, ROBSON DS and GREENE CJ (1997) Catch rate estimation for roving and access point surveys. N. Am. J. Fish. Manage. 17 11-19.

POTTS WM, COWLEY PD, CORROYER B and NÆSJE TF (2005) Trends in resource utilisation on the Great Fish Estuary. Norwegian Institute for Nature Research (NINA) Report 50. 36 pp.

PUNT A, WALKER TI, TAYLOR BL and PRIBAC F (2000) Standardization of catch and effort data in a spatially-structured shark fishery. Fish. Res. 45 129-145.

STATISTICS SOUTH AFRICA (2003) PC-AXIS Files for Subject Area Municipality Level - Persons Stats Online: Statistics South
Africa. URL: www.statssa.gov.za/timeseriesdata/pxweb2006/ Database/South\%20Africa/Population\%20Census/Census\%20 $2001 \% 20 \% 20$ NEW\%20Demarcation $\% 20$ boundaries $\% 20$ as $\% 20$ at $\% 209 \% 20$ December $\% 202005 /$ Municipality $\% 20$ level $\% 20-\% 20$ Persons/Municipality\%20level\%20-\%20Persons.asp (Accessed 1 November 2009).

STEFFANSON G (1996) Analysis of groundfish survey abundance data: combining the GLM and delta approaches. ICES J. Mar. Sci. 53 577-588.

VAN DER WAAL BCW (2000) Fish as a resource in a rural river catchment in the Northern Province, South Africa. Afr. J. Aquat. Sci. 25 56-70.

WEYL OLF (2008) Rapid invasion of a subtropical lake fishery in central Mozambique by Nile tilapia, Oreochromis niloticus (Pisces: Cichlidae). Aquat. Conserv. Mar. Freshwater Ecosyst. 18 839-851.

WEYL OLF, KAZEMBE J, BOOTH AJ and MANDERE DS (2004) An assessment of a light attraction fishery in southern Lake Malawi. Afr. J. Aquat. Sci. 29 1-11.

WEYL OLF, POTTS WM, ROUHANI QA and BRITZ P (2007) The need for an inland fisheries policy in South Africa: A case study of the North West Province. Water SA 33 497-504. 
